В. Г. Саріогло,

доктор економічних наук, старший науковий співробітник,

Doi: 10.31767/su. 2(85)2019.02.12

завідувач відділу моделювання соціально-економічних процесів і структур,

Інститут демографії та соціальних досліджень

імені М. В. Птухи НАН України,

E-mail: sarioglo@idss.org.ua

ORCID https://orcid.org/0000-0003-4381-9633

\title{
П'ята Балтійсько-Нордична конференція зі статистики обстежень
}

316 по 20 червня 2019 року у шведському місті Еребру (Örebro) відбулася 5-та БалтійськоНордична конференція зі статистики обстежень, BaNoCoSS-2019. BaNoCoSS - це наукові конференції, що відбуваються кожні чотири роки і на яких провідні науковці, фахівці, докторанти та студенти зі Швеції, Фінляндії, Естонії, Латвії, Литви, України й Білорусі представляють свої розробки з теоретико-методологічних та прикладних питань статистики вибіркових і суцільних обстежень. До участі у конференціях як ключові спікери запрошуються також провідні вчені з інших країн. Конференції BaNoCoSS-2019 організовуються Балтійсько-Північно-Українською (БНУ) мережею статистики обстежень. Попередні конференції проводилися по черзі у Швеції та Фінляндії: BaNoCoSS-2015 - у Гельсінкі (Helsinki), Фінляндія; BaNoCoSS-2011 - у Норрфеллсвікен (Norrfällsviken), Швеція; BaNoCoSS-2007 - у Куусамо (Kuusamo), Фінляндія; BaNoCoSS-2002 - в Аммарнасі (Ammarnäs), Швеція.

Організаторами конференції у 2019 році виступили науковці зі Швеції, а організаційний комітет очолював професор Томас Лайтіла (Thomas Laitila) 3 університету Еребру. Спонсорами BaNoCoSS-2019 €:

- Міжнародна асоціація статистиків з обстежень (The International Association of Survey Statisticians), мета якої - сприяти вивченню й розвитку теорії і практики вибіркових обстежень і переписів населення;

- Рада міністрів північних країн (Nordplus HE Programme);

- Асоціація (Surveyföreningen);

- Статистика Швеції (Statistics Sweden);

- Університет Еребру (Örebro university).

Перебіг конференції було організовано за такими напрямами: основні доповіді, запрошені доповіді, стендові доклади та доповіді за секціями.

Ключовими спікерами на BaNoCoSS-2019 були Роберто Бенедетті (Roberto Benedetti) професор університету Чієті-Пескара (ChietiPescara) Італія, та Федеріка Пьєрсімоні (Federica Piersimoni) з Національного інституту статистики Італіï (Italian National Statistical Institute). Серія їх доповідей була присвячена різноманітним тео- ретичним і прикладним питанням застосування просторових вибірок у дослідженнях з сільськогосподарської тематики й навколишнього середовища. Були представлені сучасні методи побудови збалансованих просторових вибірок на основі використання геоінформаційних систем та дистанційних сенсорних систем (у таких системах для отримання інформації використовуються камери, сканери, радари, радіометри тощо). Наведені приклади застосування зазначених методів при розв'язанні різноманітних статистичних задач, зокрема для визначення оптимального розміщенні заданої кількості станцій, що сприяють випадінню дощу на засушливих територіях. На увагу заслуговують такі публікації цих науковців: Agricultural Survey Methods / ed. by R. Benedetti, M. Bee, G. Espa, F. Piersimoni. Chichester: John Wiley \& Sons, Ltd, 2010. 409 p.; Benedetti R., Piersimoni F., Postiglione P. Sampling Spatial Units for Agricultural Surveys. Berlin: Springer-Verlag, 2015. 325 p.

Серед запрошених доповідей зазначимо "Використання інтегрованих геопросторових даних в офіційній статистиці”, Сюзі Джентофт (Susie Jentoft); "Використання вибіркової методології в епідеміологічних дослідженнях", Еса Лаара (Esa Läärä); “Застосування байєсівського аналізу”, Дануте Крапавіскайте (Danute Krapavickaite); “Альтернативна оцінювальна функція для коригування невідповідей”, Імбі Траат (Imbi Traat) та ін.

Основними секціями конференції були:

- дизайн вибірки;

- дизайн обстежень;

- реєстри населення;

- статистичне оцінювання на основі моделей;

- об'єднання даних з різних джерел;

- Web та он-лайн обстеження;

- оцінювання показників для регіонів (територій);

- редагування даних;

- невідповіді;

- калібрація та зважування.

Цікавими і достатньо новітніми були доповіді інших спікерів, серед яких були як постійні учасники майже всіх заходів, що проводяться в межах БНУ, так і спеціально запрошені спікери. Серед постійних учасників слід насамперед відзначити таких учених, як Карл-Ерік Сарндал 
(Carl-Erik Särndal, Швеція), Рісто Лехтонен (Risto Lehtonen, Фінляндія), Імбі Траат (Естонія), Дануте Крапавіскайте (Литва), Сеппо Лехтонен (Sерро Lehtonen, Фінляндія). Професор Рісто Лехтонен у своєму виступі, зокрема, зазначив, що в теперішній час навіть професійні статистики необгрунтовано використовують термін "репрезентативність вибірки” для позначення рівня надійності результатів вибіркових обстежень. Хоча цей термін відображає лише імовірнісний характер вибіркового обстеження і не має ніякого відношення до точності або надійності оцінювання показників за його результатами.

Серед виступів спеціально запрошених спікерів дуже цікавою і актуальною була доповідь Віри Тепел (Vera Toepel) зі статистики Норвегії “Обстеження з використанням смартфонів та сенсорні дані”. У цій доповіді було, зокрема, представлено сучасні рекомендації та досвід щодо проведення онлайн опитувань 3 використанням смартфонів. Розглянуто основні етапи таких обстежень від дизайну запитальника та окремих запитань до оцінювання показників. Обговорено переваги та недоліки онлайн обстежень, а також напрями подальших статистичних досліджень у цій сфері.

На конференції Україна була представлена достатньо численною групою науковців: I. Розора та М. Сидоров із Київського національного університету імені Тараса Шевченка; В. Саріогло та У. Лешенок з Інституту демографії та соціальних досліджень імені М. В. Птухи НАН України; Я. Бондаренко з Дніпровського національного університету імені Олеся Гончара. Участь майже всіх учасників була забезпечена завдяки підтримці спонсорів конференції. Навіть за таких пільгових умов участі, на жаль, всі представники від України були з числа постійних або майже постійних учасників заходів БНУ. Незважаючи на спеціальні запрошення, фахівці ані з Державної служби статистики України, ані з інших наукових та освітніх установ учергове не змогли взяти участь в конференції.

Наступний захід у рамках мережі БНУ відбудеться у червні 2020 року в м. Мінськ, Білорусь. 